\title{
Strategies of Green Supply Chain Practices in Construction Industry
}

\author{
P. Muralidhar
}

\begin{abstract}
Greening the supply chain practices is essential to all the sectors. Currently the management looking after the construction activities is also highly focusing on this. It is also coined as sustainable supply chain management. The sustainability is an important factor in construction industry rather than any other industries. The present research paper aimed at identifying and creating awareness of green supply chain management in materials and practices implied in Indian construction Industry. Many of the construction companies are not following sustainable practices in their day-to-day activities. There is a lot of scope to implement the sustainable practices, further helps in reducing the carbon emissions in the supply chain and helps to provide the recycling of the materials and thus reduces the wastage. This improves the construction industry economy and environment. The current research aimed at analyzing the strategies related to green supply chain management practices for construction Industry.
\end{abstract}

Index words: construction industry (ci), green supply chain management (GSCM), environment, carbon foot prints.

\section{INTRODUCTION}

The green supply chain management (GSCM) is about inducting environmental concerns in all the stages of the product development i.e from raw material stage to the finished product stage. The GSCM concept is originated from the reverse logistics. The construction Industry is consuming lot of variety of materials like cement, steel, chemicals, sand, aggregates and mixed mortar etc.. Along with all these raw materials different semi-finished or work in progress materials are also used to execute the various construction activities for their daily needs.

Mainly in the construction projects while working with mixed cement concrete, lot of cement concrete is being wasted. If the mixed concrete wastage is recycled then a good amount of savings in materials consumption takes place as well as energy consumption can be reduced to the significant level. These kinds of Green supply chain practices are quite helpful to the construction Industry to achieve carbon credits by reducing the pollution levels up to permissible limits. This results in reducing their wastage during the execution of projects and achieves the considerable profit margin in the

Revised Manuscript Received on February 05, 2020.

* Correspondence Author

Dr. P. Muralidhar, Associate Professor, National Institute f Construction Management and Research, India.

E-mail: pmuralidhar17@gmail.com

(C) The Authors. Published by Blue Eyes Intelligence Engineering and Sciences Publication (BEIESP). This is an open access article under the CC BY-NC-ND license (http://creativecommons.org/licenses/by-nc-nd/4.0/)

construction projects. If the materials used here is eco-friendly, then the construction industry is going to contribute significantly to environment and economy.

\section{THE GREEN SUPPLY CHAIN MANAGEMENT MODEL}

The Green Supply Chain Model starts from green designing of the buildings as well as promoting the usage of recyclable products, maintaining low level transportation activity in the construction site, producing the concrete with the help of green materials based cements like fly ash based cement and slag based cements etc. will definitely help to reduce the carbon foot print present in the construction industry activities. The green supply chain model adopted for Construction Industry is shown in the fig 1.

The construction supply chain is mainly classified into three types [5] [9] they are

- The "Initial supply chain focuses on delivery of basic raw materials like steel, cement, bricks etc. are used in construction applications mentioned [5].

- The support chain which provides semi-finished goods and equipment etc in construction activities.

- The human resource supply chain manages labor in construction sites.

\section{A. Green Design}

The designing aspects of product is very important for any product development and this helps to identify the eco-friendly material, process, carbon family gasses, free methods of production etc. So this has to be initiated in the design stage of the product itself. While designing the product these parameters will help to refine the process further and reduces the wastage. For all this the initiation is green design itself [3]. "The green design includes scope of usage of recyclable materials, raw material loading design, transportation model design, and unloading design etc. are the different stages of the green design" [11].

\section{B. Green Logistics}

The green logistics includes minimum transportation cost incurred, while transporting the inward goods materials as well as outward goods material. The green logistics are very important in construction supply chain because lot of internal transport activities will cause emission of gasses, improper transportation will leads to excessive budget, and high emission rate of gasses will create high pollution rate in the site. Hence the solution for all these problems is to provide greener logistics in the site mentioned by Walker [10]. 


\section{Green Construction}

In any construction site every day lot of materials are being used and most of them are excessively used than the required. This leads to higher wastage of materials and cost of construction is enhancing. Similarly lot of concrete, steel and other materials are being wasted because of improper estimation of quantity of building materials. These practices are to be curtailed as part of green construction practices. The green construction practices helps to save the environment and reduce the cost of construction and minimizes the wastage of material [7].

D. Usage of recyclable material
The "application of recyclable material is very essential in construction applications and this leads to follow the green building practices like reduce, re-use, recycle will reduce carbon foot prints, emission rate and the load on environment" as per Elizabeth Ojo [1][2][3]. Presently the green buildings became very popular because of their proved efficiency with respect to the cost and emission rate. Many "companies producing construction materials realized on the same fact that they started producing eco-friendly materials, low volatile organic component (VOC) materials etc." [1]. these practices are not enough in the present days hundred percent recyclable materials are essential for construction projects [9].

Fig.1: Green Supply Chain Model in Construction Industry

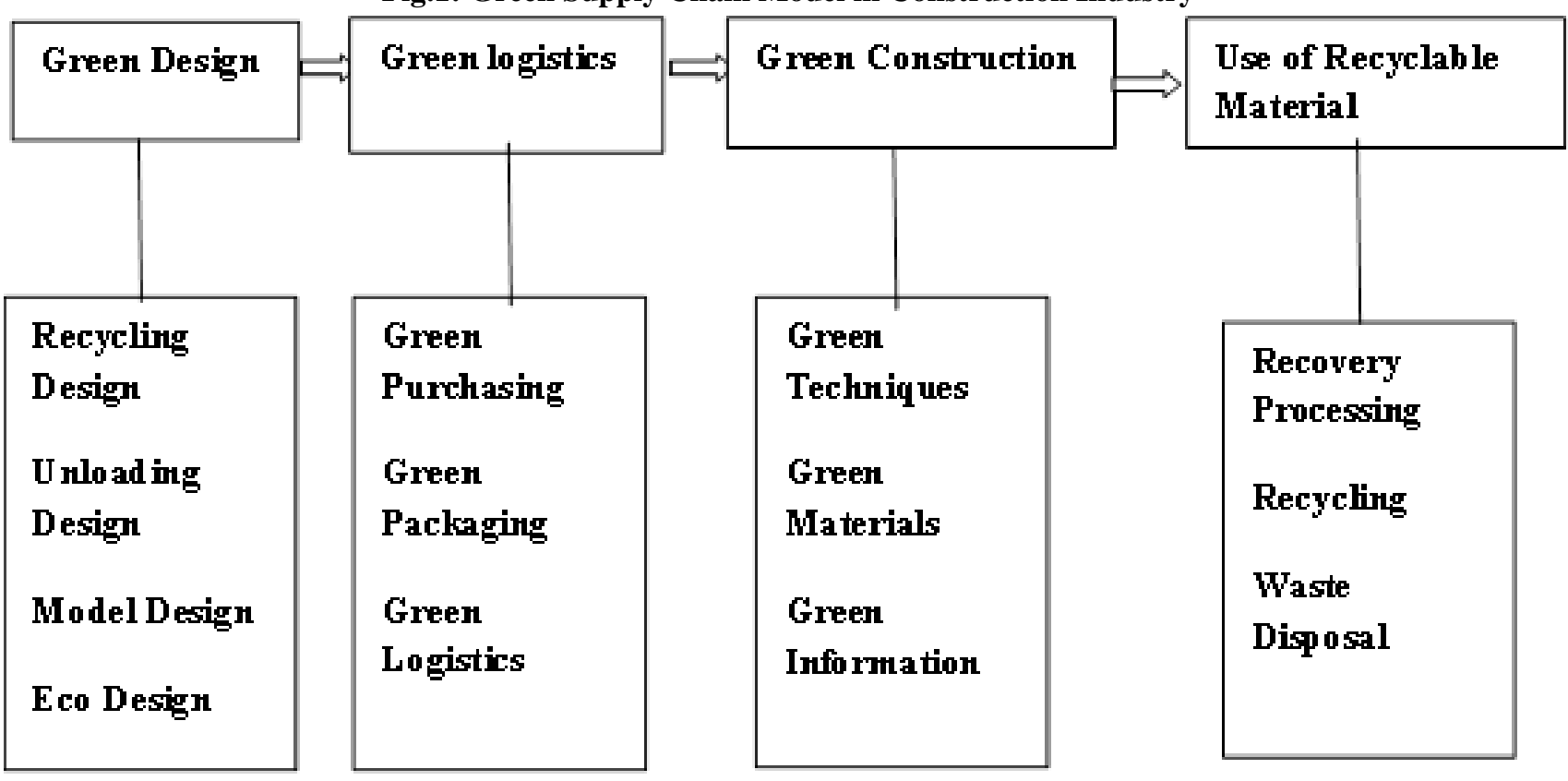

\section{METHODOLOGY}

There are many factors responsible for making the construction supply chain greener. The factors considered in the present study are taken in the form of basic raw materials, semi-finished goods, completed goods used in construction industry at different stages. The parameters portrayed in the fig. 1 starts from the designing stage of the product to the final disposal stage. The concentration of the present study is mainly on

1. To recognise the influencing factors of GSCM in Construction Industry, applying factor analysis.

2. Identifying the issues related to implement the green supply chain practices using discriminate analysis.

\section{III(A) Questionnaire survey}

The widely accepted method developed by Muniz is applied in the present research paper for "analysis of GSCM practices in construction industry"[4]. The questionnaire was prepared with 20 parameters under the category Green design, green logistics, green construction, usage of recyclable material. The questionnaire presented in the study is prepared by consulting the experts of supply chain as well as construction professionals. After conducting the reliability analysis the questionnaire was validated and finally 20 parameters are prepared to work out their options using 1-5 Likert scale(1- strongly disagree, 5-strongly agree). Under the four major parameters 20 sub parameters are identified and questionnaire was sent equally to the materials handling department, stores department line managers working in the construction site where building construction works are going on. The questionnaire was sent to 70 companies and $32(46 \%)$ companies are responded .The main purpose is to create awareness among the people and eco-friendly practices in construction activities and future scope of implementing the same. The responses are verified and suitable responses are identified for further analysis, among that 15 sub factors are considered whose correlation factor suitable for error free analysis. The factor analysis was presented in the table 1 . 
Table 1. Factor analysis

\begin{tabular}{|c|c|c|c|c|c|}
\hline Survey items & $\begin{array}{l}\text { Green } \\
\text { Design }\end{array}$ & Green logistics & Green construction & $\begin{array}{c}\text { Usage Recycle } \\
\text { material }\end{array}$ & $\begin{array}{c}\text { Crowns alpha } \\
\text { value }\end{array}$ \\
\hline $\begin{array}{ll}\text { Designing } & \text { of } \\
\text { eco-friendly product }\end{array}$ & 0.852 & 0.808 & 0.757 & 0.656 & 0.88 \\
\hline $\begin{array}{l}\text { Establishing control on } \\
\text { Environment } \\
\text { technology }\end{array}$ & 0.844 & 0.759 & 0.798 & 0.754 & 0.76 \\
\hline $\begin{array}{l}\text { Effort to minimize the } \\
\text { waste } \\
\text { manufacturing }\end{array}$ & 0.83 & 0.568 & 0.656 & 0.701 & 0.71 \\
\hline $\begin{array}{l}\text { Investment occurred to } \\
\text { adopt these technologies }\end{array}$ & 0.822 & 0.756 & 0.568 & 0.756 & 0.74 \\
\hline $\begin{array}{l}\text { Efforts to reduce } \\
\text { transportation cost }\end{array}$ & 0.744 & 0.658 & 0.721 & 0.756 & 0.76 \\
\hline $\begin{array}{l}\text { Reduction of packing } \\
\text { material cost }\end{array}$ & 0.731 & 0.756 & 0.698 & 0.722 & 0.75 \\
\hline $\begin{array}{l}\text { Usage of reuse packing } \\
\text { material }\end{array}$ & 0.544 & 0.601 & 0.598 & 0.656 & 0.71 \\
\hline $\begin{array}{ll}\begin{array}{l}\text { Implementing } \\
\text { logistics }\end{array} & \text { reverse } \\
\end{array}$ & 0.564 & 0.522 & 0.587 & 0.598 & 0.72 \\
\hline $\begin{array}{l}\text { Storage of reusable } \\
\text { packing material }\end{array}$ & 0.423 & 0.489 & 0.501 & 0.522 & 0.71 \\
\hline $\begin{array}{l}\text { Usage of eco-friendly } \\
\text { materials }\end{array}$ & 0.401 & 0.402 & 0.423 & 0.498 & 0.7 \\
\hline $\begin{array}{ll}\begin{array}{l}\text { Implementing } \\
\text { practices }\end{array} & \text { green } \\
\end{array}$ & 0.4 & 0.396 & 0.456 & 0.411 & 0.7 \\
\hline $\begin{array}{l}\text { Sharing the information } \\
\text { to suppliers }\end{array}$ & 0.412 & 0.422 & 0.455 & 0.421 & 0.7 \\
\hline $\begin{array}{lc}\text { Suppliers } & \text { awareness } \\
\text { about EMS practices }\end{array}$ & 0.456 & 0.45 & 0.487 & 0.467 & 0.75 \\
\hline $\begin{array}{ll}\begin{array}{l}\text { Implementing } \\
\text { practices }\end{array} & \text { ISO } \\
\end{array}$ & 0.489 & 0.423 & 0.494 & 0.498 & 0.71 \\
\hline $\begin{array}{l}\text { Masons awareness about } \\
\text { EMS practices while } \\
\text { working }\end{array}$ & 0.425 & 0.685 & 0.657 & 0.752 & 0.79 \\
\hline
\end{tabular}

\section{RESULTS AND DISCUSSIONS}

Factor analysis is carried out and variations have been analyzed using discriminate analysis. The truthful responses were tested to examine the soundness and reliability of the scale to enable a statistically proven documentation of the responses. Factor analysis is applied to responses using principal component method \& varimax rotation in SPSS 20.0.The data was tested for internal consistency by figuring
Cronbach's Alpha $(\alpha)$ is 0.7 and above is considered and is tabulated in the table 2.

Linear discriminate analysis is conducted for the factors mentioned using SPSS 20.0 and the results are tabulated in table 2 and table 3 respectively. The results portrays that using of recyclable material is very important in construction activities and green logistics has got the lowest priority.The mean values for these comparison parameters portrayed in table 3 shows very high consistency with min marginal difference of 0.005 to 0.016 .

Table 2. Comparison of mean values and $t$-test

\begin{tabular}{|c|c|c|c|}
\hline Comparison parameters & Mean & T test & Remarks \\
\hline Green design Vs Green logistics & 0.595 and 0.579 & 0.571 & Acceptable \\
\hline Green design VS Green Construction & 0.595 And 0.590 & 0.186 & Acceptable \\
\hline Green design Vs Recycling material & 0.595 and 0.611 & -0.494 & Acceptable \\
\hline Green logistics Vs Green Construction & 0.579 and 0.590 & 0.570 & Acceptable \\
\hline Green logistics Vs Recycling material & 0.579 and 0.611 & 0.582 & Acceptable \\
\hline
\end{tabular}


Strategies of Green Supply Chain Practices in Construction Industry

Green Construction Vs Recycling material

0.590 and 0.611

0.580

Acceptable

Table 3. Correlation of Paired Samples

\begin{tabular}{|c|c|c|c|c|c|}
\hline \multicolumn{2}{|c|}{ Parameters } & N & Correlation & Sig. & Remarks \\
\hline Pair 1 & Green design \& Green logistics & 15 & 0.805 & 0.000 & Acceptable \\
\hline Pair 2 & Green design \& Green construction & 15 & 0.809 & 0.000 & Acceptable \\
\hline Pair 3 & Green design \& Recycling material used & 15 & 0.758 & 0.001 & Acceptable \\
\hline Pair 4 & Green logistics Vs Green Construction & 15 & 0.790 & 0.002 & Acceptable \\
\hline Pair 5 & Green logistics Vs Recycling material & 15 & 0.785 & 0.005 & Acceptable \\
\hline Pair 6 & Green Construction Vs Recycling material & 15 & 0.810 & 0.007 & Acceptable \\
\hline
\end{tabular}

\section{CONCLUSIONS}

Construction Industry is well known for usage of large variety of materials throughout the project compared to other industries. For implementing the green supply chain practices requires lot of attention and care is required. Therefore the essential thing is construction industry needs to encourage the usage of recyclable materials. The same results were displayed in the factor analysis table, followed by green design, green construction and green logistics. The above factors discussed in the paper shows that the awareness towards green aspects is increasing day by day from the mason level on wards. This awareness will be helpful to the masons while working to identify the difference between green construction material and non-green construction material. If the green materials are used in the large scale manner in any construction related projects would be helpful for reduction of greenhouse gasses and provides safer environment in the construction site.

\section{REFERENCES}

1. Balasubramanian, S., 'A structural analysis of green supply chain management enablers in the UAE construction sector', International Journal of Logistics Systems and Management,2014, 19(2), pp. 131-150.

2. Elizabeth Ojo, Charles Mbohwa, and Esther Akinlabi "Green supply chain management in construction industries in south africa and Nigeria” International Journal of Chemical, Environmental \& Biological Sciences (IJCEBS) Volume 2, ISSN 2320-4087 (Online) pp 147-150.

3. Elizabeth Ojo et.al, Barriers in Implementing Green Supply Chain Management in Construction, Industry Proceedings of the 2014 International Conference on Industrial Engineering and Operations Management Bali, Indonesia, January 7 - 9, 2014.

4. Muniz B.F., Manuel-Peon J.M., Azquez Ordas, C.J., Relation between occupational safety management and firm performance, Safety Science, 47(7),2009, pp 980-99.

5. Muralidhar $\mathrm{P}$, Ravindranath $\mathrm{K}$, Srihari V "Perspective patterns of environmental green supply chain management", July-Dec 2010 , Vol3, issue 2, pp233-237.

6. O’Brien, W., Construction supply-chains: Case study, integrated cost and performance analysis. " Proc. 3rd Ann. Conf. Int'1. Group for Lean Construction, Albuquerque.

7. Ojo, E, Akinlabi E.T and Mbohwa C (2012), Benefits of green supply chain management in construction firms - a review, 2nd Nelson Mandela Metropolitan University, Construction management conference.

8. Pankaj Srivastav, Manoj Kumar Gaur(2015), Scope Of Green Supply Chain Management In North Indian Construction Industries, International Journal of Advanced Research in Engineering and Applied Sciences Vol 4, No 4,2015, pp 53-73 ISSN: 2278-6252.

9. Prince boadu, Embracing (2014) Embracing Green Supply Chain Practices In The Construction Industry; The Case of Construct firm Kumasi metro polis and its environs Research Journals of management PP Vol 2, No 6 July 2014.

10. Walker, H., Di Sisto, L.\& McBain, D, Drivers and Barriers to environmental offer chain management practices: Lessons from the general public and personal sectors. Journal of purchasing and supply chain management, 14(1),2008, 69-85.
11. Xiao X. (2006). Green offer Chain Management within the kingdom and China industry, A master's degree thesis submitted at School of Environmental Sciences, University of East Anglia, Norwich NR4 7TJ.

\section{AUTHORS PROFILE}

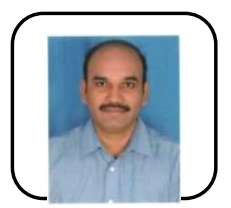

Dr. P. Muralidhar, is working as $\mathrm{Sr}$ Associate Professor in National Institute $f$ Construction Management And Research, India. His main research Interest Includes project management, Operations Management, Risk Management. 